\title{
Radioprotection : la voie à suivre
}

Le nouveau comité éditorial de Radioprotection a été mis en place il y a un an. Déjà un an! Je voudrais remercier chaleureusement mes collègues co-éditeurs pour leur engagement et leur excellent travail. Dans notre article « Radioprotection: Quel avenir?» publié dans le $1^{\mathrm{er}}$ numéro de la revue en 2017, nous avions clairement indiqué notre souhait d'une nouvelle ligne éditoriale centrée sur les questions essentielles, avec priorité donnée à la radioprotection, l'épidémiologie, la radiobiologie, la dosimétrie physique et biologique, la radiotoxicologie, l'écotoxicologie et la protection de l'environnement. Les enjeux liés aux rayonnements non ionisants sont aussi intégrés au sein de cette nouvelle ligne éditoriale. Cette année, des articles de grande qualité ont été publiés. Nous avons introduit les commentaires éditoriaux afin de promouvoir le débat et la discussion en profondeur des résultats de la recherche. Les deux sections « La vie des PCR » et «La vie réglementaire » du Magazine de la SFRP contribuent à la pratique quotidienne de nos lecteurs. Nous voudrions remercier tous les lecteurs qui, par leur réponse à notre questionnaire ou directement, ont signifié leur satisfaction et leur support à la nouvelle ligne éditoriale. J'ai donc le sentiment que nous sommes sur la bonne voie. Nous allons continuer d'améliorer la qualité scientifique et l'attractivité de notre journal comme demandé et espéré par notre lectorat. L'investissement des auteurs est indispensable pour parvenir à cette fin, et nous les remercions vivement pour leurs contributions. Votre participation à la vie de notre journal Radioprotection est donc la bienvenue.

Enfin, je vous invite à découvrir dans ce numéro deux articles importants : l'un sur la structuration de la recherche européenne de ces huit dernières années sur les effets des faibles doses, et l'autre sur le risque de développer un cancer du sein radio-induit chez les porteurs de la mutation BRCA.

En attendant vos contributions, je vous souhaite une bonne lecture de ce nouveau numéro de Radioprotection.

\section{Radioprotection, the way forward}

The new editorial team of Radioprotection took office a year ago. One year already! I would like to warmly thank my colleagues co-editors for their commitment and their excellent work. With our joint article entitled "Radiation protection: what's next?" published in the 1st issue of 2017 we clearly indicated our wish for a new editorial line focused on the key issues to be addressed with priority given for radiological protection, epidemiology, fundamental radiation biology, biological and physical dosimetry, radiation toxicology, ecotoxicology and environmental radiation protection. Non ionizing radiation key issues are indeed part of this new line. Highly valuable papers have been published this year. We have introduced Editorial Comments as a way to promote the debate and to discuss in depth research findings. We are pleased that both sections "La vie des PCR" and "La vie réglementaire" of the Magazine of SFRP contribute to the everyday practice of our readers. We would like to thank all our readers who responded to our questionnaire, notified their appreciations and support to the new editorial line. Thus I have the feeling that we are on the right way. We are going to keep on improving both scientific quality and attractiveness of our journal as requested and expected by our lectorship. To achieve this, a key point is also the investment of our authors whom we warmly thank for their contribution. Thus your participation in the life of our journal Radioprotection is very welcome.

Finally I invite you to discover in this issue, two important articles on the structuring in the past eight years of the low dose effects research in Europe and on the radiation-induced risk of breast cancer in BRCA mutation carriers.

While waiting for your contributions, I wish you a pleasant reading of this new issue of Radioprotection.

M. Bourguignon

Rédacteur en chef 